\title{
Radioprotection : continuons ensemble
}

Il y a un an, le nouveau comité éditorial de Radioprotection publiait un article intitulé «Radioprotection: quel avenir?» proposant une ligne éditoriale ouverte à tous les thèmes de la radioprotection. À la suite de la publication du $4^{\mathrm{e}}$ et dernier numéro de 2017, une première analyse du chemin parcouru peut être réalisée.

En 2017, nous avons publié 29 articles ( 9 en français et 20 en anglais) et 2 commentaires éditoriaux en anglais. Aujourd'hui, tous les articles en français contiennent un résumé en anglais, cependant l'inverse n'est pas vrai, et nous nous interrogeons sur l'opportunité de le mettre en place.

Alors qu'en 2016 les articles concernaient l'environnement (17), les expositions médicales (8), la dosimétrie (8) et la radioprotection en général (1), ceux de 2017 ont été plus variés : environnement (11), radioprotection (4), radiobiologie (4), expositions médicales (3), dosimétrie (2), épidémiologie (2), radiotoxicologie (2), rayonnement non ionisant (2) et réglementation (1). Comme nous le souhaitions, une plus grande diversité des sujets est au rendez-vous - merci à tous les auteurs - et l'effort est à poursuivre.

Dans ce numéro, nous avons le plaisir de publier une lettre à l'éditeur et la réponse des auteurs. C'est un signe que la question du risque lié aux expositions mammographiques des femmes présentant un risque familial de cancer lié à une mutation BRCA, soulevée par C. Colin et al., est une question pertinente, au carrefour de l'épidémiologie, de la radiobiologie et de l'évaluation du risque. Dans ce numéro, vous trouverez aussi un article de synthèse et d'analyse des forces et des faiblesses du système français des niveaux de référence diagnostiques en radiologie, mis en place et géré par l'institut de radioprotection et de sûreté nucléaire (IRSN). Enfin, une enquête originale sur les maladies professionnelles radio-induites reconnues depuis 1956 et d'autres articles intéressants en radioprotection médicale et dosimétrie sont aussi publiés.

Continuons ensemble en 2018 pour un journal encore meilleur!

\section{Radioprotection: let's keep forward together}

A year ago, the new editorial team of Radioprotection published in the 1st issue of 2017 an article entitled "What's next in Radioprotection?" calling for papers in a large variety of domains. After the publication of the 4th and last issue of 2017, a first evaluation in depth can be done.

We published 29 articles ( 9 in French and 20 in English) and 2 editorial comments in English. The articles in French have an abstract in English but the opposite is not true and we wonder about the opportunity to do it.

While in 2016 articles concerned environment (17), medical exposures (8), dosimetry (8) and general radiological protection (1), articles in 2017 dealt with a larger variety of subjects as wished: environment (11), radiological protection (4), radiation biology (4), medical exposures (3), dosimetry (2), epidemiology (2), radiotoxicology (2), non-ionizing radiation (2) and regulation (1). Efforts are still required to ensure this necessary diversity.

In the current issue, we are pleased to publish a letter to the Editor and the response from the authors. It is a sign that the question of the risk of mammographic exposure in patients with a family risk of cancer related to BRCA mutation raised by C. Colin et al. is a deemed right question of radiological protection at the cross road of epidemiology, radiation biology and risk evaluation. In this issue, you will also find an article regarding the strength and weaknesses of the French diagnostic reference levels system in radiology managed by the institute of radiological protection and nuclear safety (IRSN). Finally, a survey regarding radio-induced occupational diseases recognized in France since 1956 and other interesting articles in medical radiological protection and dosimetry are also published.

Let's keep forward together in 2018 for a still better journal! 